\title{
GLOBALIZAÇÃO, INVISIBILIDADE SOCIAL E RECONHECIMENTO: UMA ANÁLISE DA (SO)NEGAÇÃO DE DIREITOS DOS CATADORES DE MATERIAIS RECICLÁVEIS
}

\author{
GLOBALIZATION, SOCIAL INVISIBILITY AND RECOGNITION: AN ANALYSIS \\ OF THE RECYCLABLE MATERIALS COLECTOR'S RIGHTS (NOT) GRANT
}

\author{
GLOBALIZACIÓN, INVISIBILIDAD SOCIAL Y RECONOCIMIENTO: UN ANÁLISIS \\ DE LA (SO)NEGACIÓN DE DERECHOS DE LOS CATADORES DE MATERIALES \\ RECICLABLES
}

\section{Nelson Camatta Moreira}

http://orcid.org/0000-0002-8295-4275 / http://lattes.cnpq.br/2535094687665916 / nelsoncmoreira@hotmail.com Doutorado em Direito (UNISINOS-RS), com estágio de pesquisa anual na Universidade de Coimbra, com bolsa CAPES. Líder do Grupo de Pesquisa CNPq "Teoria Crítica do Constitucionalismo", da FDV-ES. Professor da Programa de Pósgraduação Stricto Sensu (Doutorado e Mestrado) e da Graduação em Direito da FDV-ES. Membro Honorário e vicePresidente da Rede Brasileira Direito e Literatura (RDL). Vitória, ES, Brasil.

\section{PRISCILA TINELLI PINHEIRO}

http://orcid.org/0000-0002-0452-5344 / http://lattes.cnpq.br/5573643379979957 / priscilatinelli@hotmail.com Doutoranda e Mestre em Direitos e Garantias Constitucionais pela Faculdade de Direito de Vitória (FDV). Membro do Grupo de Pesquisa "Invisibilidade social e energias emancipatórias em direitos humanos" da Faculdade de Direito de Vitória (FDV). Advogada. Vitória, ES, Brasil.

\begin{abstract}
RESUMO
O presente estudo pretende abordar um fenômeno gerado pelas consequências nefastas da globalização que é justamente a formação de um mercado e de profissões informais. Pretende-se, portanto, mostrar as implicações que essa transformação econômica acarreta no aspecto social do país, como o exemplo do aumento do índice de desempregos e a perda de espaço das empresas cuja produção é voltada exclusivamente para o âmbito local. Dessa forma, a partir da análise de um grupo social específico - os catadores de materiais recicláveis - o qual surgiu em um cenário de busca por alternativas ao desemprego, serão apresentados os principais obstáculos enfrentados por indivíduos vítimas do fenômeno da invisibilidade social ao adequado reconhecimento e, para tanto, será utilizada a teoria do reconhecimento em Axel Honneth (2007). Objetiva-se a análise, por meio da pesquisa de cunho bibliográfico, em face do processo de globalização, dos fatores que impedem que um grupo social vítima do fenômeno da invisibilidade pública obtenha um reconhecimento pleno perante o Estado e a sociedade da qual faz parte. Como principais resultados, evidencia-se que o acesso deficitário aos direitos básicos, mesmo diante das conquistas alcançadas pelo grupo em análise, constitui o principal obstáculo a este reconhecimento.
\end{abstract}

Palavras-chave: Catadores de materiais recicláveis; Direitos sociais; Globalização; Invisibilidade social; Teoria do reconhecimento. 


\section{ABSTRACT}

The present study aims to address a phenomenon generated by the harmful consequences of globalization, which is precisely the formation of a market and informal professions. It is intended, therefore, to show that the implications of this economic transformation in the social aspect of the country, such as the increase in the unemployment rate and a loss of space for local production companies. Thus, from the analysis of a specific social group - the recyclable material collectors - which emerged in a scenario of search for alternatives to unemployment, this work will demonstrate the main obstacles faced by those individuals who are victims of the phenomenon of invisibility. To achieve such goal, the Axel Honneth (2007) theory of recognition will be used. The objective of this study, made through bibliographic research, is to analyze the factors that prevent a social group (victim of the phenomenon of public invisibility) from obtaining full recognition from the State and society of which it is a member. As main results, it is evident that the deficient access to the basic rights, even in face of the achievements reached by the group under analysis, is the main obstacle to this recognition.

Keywords: Recyclable material collectors; Social rights; Globalization; Social invisibility; Recognition theory.

\section{RESUMEN}

El presente estudio pretende abordar un fenómeno generado por las consecuencias nefastas de la globalización que es justamente la formación de un mercado y de profesiones informales. Se pretende, por lo tanto, mostrar las implicaciones que esa transformación económica acarrea en el aspecto social del país, como el ejemplo del aumento del índice de desempleados y la pérdida de espacio de las empresas cuya producción se dirige exclusivamente al ámbito local. De esta forma, a partir del análisis de un grupo social específico - los recolectores de materiales reciclables - el cual surgió en un escenario de búsqueda por alternativas al desempleo, se presentarán los principales obstáculos enfrentados por individuos víctimas del fenómeno de la invisibilidad social al adecuado reconocimiento y para lo cual se utilizará la teoría del reconocimiento en Axel Honneth (2007). Se objetiva el análisis, a través de la investigación de cuño bibliográfico, frente al proceso de globalización, de los factores que impiden que un grupo social víctima del fenómeno de la invisibilidad pública obtenga un reconocimiento pleno ante el Estado y la sociedad de la que forma parte. Como principales resultados, se evidencia que el acceso deficitario a los derechos básicos, incluso ante las conquistas alcanzadas por el grupo en análisis, constituye el principal obstáculo para este reconocimiento.

Palabras clave: Recolectores de materiales reciclables; Derechos sociales; Globalización; Invisibilidad social; teoría del reconocimiento.

\section{SUMÁRIO}

INTRODUÇAO; 1 O FENÔMENO DA GLOBALIZAÇÃO E SEUS EFEITOS NA AMÉRICA LATINA; 2 ANÁLISE DAS ETAPAS DA TEORIA DO RECONHECIMENTO EM AXEL HONNETH; 3 CATADORES DE MATERIAIS RECICLÁVEIS: OS INVISÍVEIS DA SOCIEDADE GLOBALIZADA; CONCLUSÃO; REFERÊNCIAS.

\section{INTRODUÇÃO}

O fenômeno da globalização, observado em sua vertente neoliberal, que avança no mundo ocidental desde o final da década de setenta e início da de oitenta vem promovendo impactos no Estado e na sociedade brasileiros e seus efeitos perversos podem ser notados em diferentes aspectos na vida e na dignidade das pessoas.

Nesse sentido, a globalização - ao relacionar a economia de um país com diversas outras nações do mundo - causa inúmeras consequências, sendo que a que mais nos interessa - nesse 
estudo - é o desemprego e a falta de competitividade das empresas que não são consideradas “multinacionais". E isso ocorre, principalmente, porque o mercado nacional e local - aquele abrangido pelas empresas menores - perde espaço frente a esse processo de expansão da economia.

Assim, surge a necessidade de que a parcela da população que sofre diretamente os efeitos do referido processo procure alternativas a tal situação em busca de vencer os obstáculos - expandidos no atual contexto - ao devido reconhecimento. Esse reconhecimento será analisado à luz das considerações de Axel Honneth acerca da teoria do reconhecimento - em que são propostas as etapas do amor, do direito e da solidariedade para que se complete tal ciclo.

Para tanto, elegeu-se o grupo social dos catadores de materiais recicláveis a fim de analisar o processo de reconhecimento que eles ainda enfrentam para se estabelecer perante a sociedade brasileira e, nesse contexto, será apresentado o surgimento da atividade desenvolvida por eles no Estado brasileiro e sua histórica luta de sobrevivência.

Importante ressaltar, que será utilizado o conceito desenvolvido por Fernando Braga da Costa referente à invisibilidade pública e a sua relação com o processo de reconhecimento. $\mathrm{E}$ tudo isso será aplicado, de forma específica, no caso dos catadores brasileiros.

Desta feita - e partindo do pressuposto de que os temas que envolvem este trabalho são a globalização, a teoria do reconhecimento e a invisibilidade social -, como forma de problematizar o presente estudo, será proposto um objetivo geral - que pode ser considerado como fio-condutor e que se pretende, em última análise, examinar - qual seja: o fenômeno da invisibilidade social, por si só, é um fator impeditivo ao reconhecimento dos catadores de materiais recicláveis na sociedade globalizada?

Portanto, o objetivo geral da pesquisa, gira em torno da delimitação dos fatores que impedem um grupo social, vítima do fenômeno da invisibilidade pública, de obter o reconhecimento pleno perante o Estado e a sociedade da qual faz parte. Como objetivos específicos, pretende-se: verificar como se desenvolve o processo de globalização, bem como as consequências ocasionadas por ele na sociedade; num segundo momento, analisar as etapas da teoria do reconhecimento com base nos ensinamentos de Axel Honneth; e, finalmente, apresentar o conceito de invisibilidade pública e discutir os obstáculos que tal situação, na sociedade globalizada, causa ao reconhecimento dos catadores de materiais recicláveis. 
Sendo assim, propõe-se o desenvolvimento do presente estudo por intermédio de uma pesquisa de cunho bibliográfico, vale dizer, partir-se-á do exame de referenciais teóricos que abordem os temas apresentados, propondo-se um diálogo e uma contraposição de ideias, ampliando-se, assim, o debate, visando à construção dialética e provisória de um novo saber ou uma nova concepção do tema proposto, sem a pretensão de esgotá-lo.

\section{FENÔMENO DA GLOBALIZAÇÃO E SEUS EFEITOS NA AMÉRICA LATINA}

A sociedade, desde a sua criação, passa por revoluções sociais, políticas, econômicas, culturais, que influem na modificação de conceitos científicos. A todo momento as ciências têm que adequar suas teorias de modo a acompanhar a realidade que está posta no mundo social.

Nesse sentido, a cada nova importante modificação surge, por conseguinte, um novo paradigma a ser compreendido e ultrapassado. De acordo com Thomas Kuhn ${ }^{1}$, paradigmas podem ser entendidos como "[...] as realizações científicas universalmente reconhecidas que, durante algum tempo, fornecem problemas e soluções modelares para uma comunidade de praticantes de uma ciência".

Durante muito tempo, a sociedade e as relações de seus integrantes foram estudadas a partir da comunidade em que eles habitavam e, além disso, o limite para a compreensão dessas variáveis era o próprio território do país. Contudo, o processo de globalização veio para transformar todas essas concepções até então adotadas pelas ciências.

A análise do processo de globalização perpassa, dessa forma, pela análise das próprias teorias sociais, as quais precisam se adequar a esse novo modelo de sociedade, já que agora não é possível que as relações sejam observadas somente com base nos limites territoriais de um Estado-nação.

Acerca dessa situação, Octávio lanni² salienta que “[...] o paradigma clássico, fundado na reflexão sobre a sociedade nacional, está sendo subsumido formal e realmente pelo novo paradigma, fundado na reflexão sobre a sociedade global”. Assim, estamos diante de uma importante mudança por meio da quebra de paradigma, pois o atual já não mais atende a presente realidade social.

\footnotetext{
${ }^{1}$ KUHN, Thomas S. A estrutura das revoluções científicas. Tradução de Beatriz Vianna Boeira e Nelson Boeira. 6. ed. São Paulo: Perspectiva, 2001. p. 13.

${ }^{2}$ IANNI, Octávio. A sociedade global. 8. ed. Rio de Janeiro: Civilização Brasileira, 1999. p. 239.
} 
GLOBALIZAÇÃO, INVISIBILIDADE SOCIAL E RECONHECIMENTO: UMA ANÁLISE DA (SO)NEGAÇÃO DE DIREITOS DOS CATADORES DE MATERIAIS RECICLÁVEIS

Nelson CAMATta MOREIRA PRISCILA TINELLI PINHEIRO

O referido autor acrescenta à reflexão sobre o novo paradigma vigente, a questão da insuficiência de conhecimentos para estudar o processo de globalização, o que pode ser evidenciado na seguinte passagem:

o conhecimento acumulado sobre a sociedade nacional não é suficiente para esclarecer as configurações e os movimentos de uma realidade que já é sempre internacional, multinacional, transnacional, mundial ou propriamente global. $\dot{E}$ óbvio que a sociedade nacional continua a ter vigência com seu território, sua população, seu mercado, sua moeda, seu hino, sua bandeira, seu governo, sua constituição, sua cultura, sua religião, sua história, e demais formas de organização social e técnica do trabalho, façanhas, heróis, santos, monumentos, ruínas. [...] Mas a sociedade nacional não dá conta, nem empírica, nem metodologicamente, nem histórica ou teoricamente, de toda realidade na qual se inserem indivíduos e classes, nações e nacionalidades, culturas e civilizações. Aos poucos, e às vezes de repente, a sociedade global subsume formal ou realmente a sociedade nacional, compreendendo indivíduo, grupo, classe, movimento social, cultura, língua, religião, moeda, mercado, formas de trabalho, modos de vida. Tudo isto continua vigente, como nacional, com toda sua forma original. Mas tudo isto, simultaneamente, articula-se dinâmica e contraditoriamente com as configurações e os movimentos da sociedade global ${ }^{3}$.

Fala-se em processo de globalização, pois esse fenômeno ainda não está completamente estabelecido em todos os países do globo, por exemplo, a África e os países da América Latina.

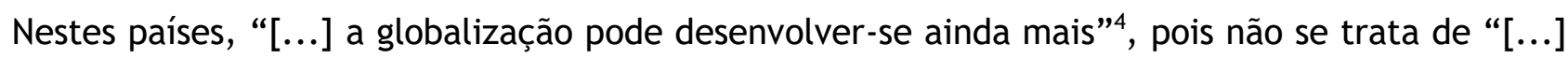
um fato acabado, mas um processo em marcha. Enfrenta obstáculos, sofre interrupções, mas generaliza-se e aprofunda-se como tendência"5.

O processo de globalização possui variadas faces: econômica, política, social, cultural. No presente trabalho, analisar-se-á a globalização tomando por base as suas repercussões nas questões econômicas dos países, porém tal estudo não seria possível sem que fossem observados os impactos dessas questões nas demais faces do processo, bem como as consequências sofridas pela sociedade.

No que tange às múltiplas faces da globalização, Boaventura de Sousa Santos ${ }^{6}$ adverte que

\footnotetext{
${ }^{3}$ IANNI, Octávio. A sociedade global. 8. ed. Rio de Janeiro: Civilização Brasileira, 1999, p. 239-240.

${ }^{4}$ Ibidem. p. 23.

${ }^{5}$ Ibidem.

6 SANTOS, Boaventura de Sousa. Os processos da globalização. In: SANTOS, Boaventura de Sousa. A globalização e as ciências sociais. São Paulo: Cortez Editora, 2011, p. 55.
} 
GLOBALIZAÇÃO, INVISIBILIDADE SOCIAL E RECONHECIMENTO: UMA ANÁLISE DA (SO)NEGAÇÃO DE DIREITOS DOS CATADORES DE MATERIAIS RECICLÁVEIS

[...] aquilo que habitualmente designamos por globalização são, de facto, conjuntos diferenciados de relações sociais; diferentes conjuntos de relações sociais dão origem a diferentes fenómenos de globalização. Nestes termos, não existe estritamente uma entidade única chamada globalização; existem, em vez disso, globalizações; em rigor, este termo só deveria ser usado no plural.

Da mesma forma, Hinkellammert ${ }^{7}$ descreve três dimensões sobre as quais recaem os ajustes estruturais originados da estratégia adotada pelo processo da globalização na América Latina, quais sejam:

A) La apertura tendencialmente ilimitada para el capital financeiro y para las corrientes de divisas y de mercancias.

B) La reestructuración del Estado em la dirección de um Estado policial y militar. De este modo pareciera que el Estado policial significaba libertad, y el Estado social, esclabitud. Se le quitó al Estado sus funciones en política de desarrollo y em política sobre infraestructura económica y social. De eso se derivaba la privatización de las propiedades públicas, lo que dio lugar a uma nueva acumulación originaria. A partir de lo cual, aparecerá em el mundo enterro un pillaje de estas propiedades.

C) La flexibilización de la fuerza de trabajo, lo que trae consigo la anulación de derechos de importancia decisiva, que eram el resultado del contrato de trabajo como protección frente al despido, y la proteción de la mujer, pero también de los niños, etc. Las seguridades sociales quedan disueltas, y los sindicatos debilitados, muchas veces hasta su disolución.

Nota-se, com estas afirmações, que as transformações ocorridas em cada uma das faces da globalização repercutem nas demais, tendo em vista que não se pode analisar, por exemplo, a economia de um país sem observar os impactos sofridos nas relações sociais desse mesmo Estado. Todas as faces da globalização estão, portanto, interligadas.

As mudanças ocasionadas na economia fizeram com que ela se transformasse, nesse novo século, em uma economia global, mas não mais uma economia pensada nos limites do território do estado - uma economia nacional. Podem ser citadas como algumas dessas mudanças, as seguintes situações:

[...] economia denominada pelo sistema financeiro e pelo investimento à escala global; processos de produção flexíveis e multilocais; baixos custos de transporte; revolução nas tecnologias de informação e de comunicação; desregulação das economias nacionais; preeminência as agências financeiras

\footnotetext{
${ }^{7}$ HINKELAMMERT, Franz J. El proceso actual de globalización y los derechos humanos. In: FLORES, Joaquín Herrera et at (Org.). El vuelto de anteo: derechos humanos y crítica de la razón liberal. Palimpsesto: Desclée de Brouwer, 2000. p. 117-118.
} 
GLOBALIZAÇÃO, INVISIBILIDADE SOCIAL E RECONHECIMENTO: UMA ANÁLISE DA (SO)NEGAÇÃO DE DIREITOS DOS CATADORES DE MATERIAIS RECICLÁVEIS

Nelson CAMATtA MOREIRA PRISCILA TINELLI PINHEIRO

multilaterais; emergência de três grandes capitalismos transnacionais: o americano, baseado nos EUA e nas relações privilegiadas deste país com o Canadá, o México e a América Latina; o japonês, baseado no Japão e nas suas relações privilegiadas com os quatro pequenos tigres e com o resto da Ásia; e o europeu, baseado na União Europeia e nas relações privilegiadas desta com a Europa de Leste e com o Norte de África ${ }^{8}$.

Em contrapartida, essas transformações na economia mundial oriundas da globalização não trouxeram somente benefícios para o Estado, pelo contrário, todo esse processo foi responsável por agravar ainda mais as desigualdades entre os países - já estabelecida em virtude da ocidentalização - e também entre as classes sociais existentes no interior do país.

Destaca-se que o processo de globalização distanciou ainda mais algumas classes, tendo em vista que o impacto sofrido em cada uma delas deu-se de maneira distinta. Assim, “uma parte integrante dos processos de globalização é a progressiva segregação espacial, a progressiva separação e exclusão" .

Nota-se, nesse sentido, que “[...] a globalização não é jamais um processo históricosocial de homogeneização, embora sempre estejam presentes forças empenhadas na busca de tal fim; [...] Esta é uma herança antiga, um traço marcante na história da ocidentalização do mundo" ${ }^{10}$.

Em consonância com as já citadas consequências originadas pelo processo de globalização, Boaventura de Sousa Santos ${ }^{11}$ destaca algumas situações que constituem os resultados desse processo, tais como:

[...] o aumento dramático das desigualdades entre países ricos e pobres e, no interior de cada país, entre ricos e pobres, a sobrepopulação, a catástrofe ambiental, os conflitos étnicos, a migração internacional massiva, a emergência de novos Estados e a falência ou implosão de outros, a proliferação de guerras civis, o crime globalmente organizado, a democracia formal como uma condição política para a assistência internacional, etc.

\footnotetext{
${ }^{8}$ HINKELAMMERT, Franz J. El proceso actual de globalización y los derechos humanos. In: FLORES, Joaquín Herrera et at (Org.). El vuelto de anteo: derechos humanos y crítica de la razón liberal. Palimpsesto: Desclée de Brouwer, 2000, p. 29.

9 BAUMAN, Zygmunt. Globalização: as consequências humanas. Tradução de Marcus Penchel. Rio de Janeiro: Jorge Zahar Ed., 1999. p. 9.

${ }^{10}$ IANNI, Octávio. A sociedade global. 8. ed. Rio de Janeiro: Civilização Brasileira, 1999. p. 128-129.

11 SANTOS, Boaventura de Sousa. Os processos da globalização. In: SANTOS, Boaventura de Sousa. A globalização e as ciências sociais. São Paulo: Cortez Editora, 2011, p. 126.
} 
É inegável, desse modo, que a globalização é um fenômeno que acarreta desenvolvimento para os países em variados setores, o que, por outro lado, tem drásticas consequências para a população, em especial, as classes mais baixas. E essa situação advém, dentre outros fatores, do fato de que com o estabelecimento da globalização, a economia destina-se a produzir bens e serviços com pouca durabilidade com o objetivo de acelerar o consumo.

Com isso, verifica-se a precarização da oferta e das condições de trabalho culminando em consequências como a intensificação de contratações ou de trabalhos temporários, para atender essa grande demanda do mercado, o que pode, por um lado, ser considerado uma alternativa para quem encontra-se desempregado, mas por outro é uma forma de aumento do desemprego a longo prazo, pois não se é permitido a formação de um vínculo duradouro com o estabelecimento empregador, já que o trabalhador tem um tempo determinado para ser “descartado" na medida em que for atendida aquela demanda de produção.

A partir dessas considerações, nota-se que a economia, em tempos de globalização, é transformada em algo efêmero e precário, tendo em vista a durabilidade dos bens e produtos e os trabalhos temporários, respectivamente. Dessa forma, cada vez mais as grandes empresas, consideradas as multinacionais - que estabelecem relações mercantis com vários países do globo - tomam conta do mercado e aniquilam aquelas que mantêm uma produção voltada exclusivamente para o âmbito local e nacional.

Assim, uma das principais consequências desse monopólio econômico é o crescimento de uma parcela da população que não se encaixa na atual realidade do mercado - os "excluídos" da sociedade - ou seja, os indivíduos que não detêm capacidade produtiva, que, por conseguinte, serão destinados a viverem à margem da sociedade.

Em uma tentativa de driblar os efeitos do processo de globalização e, com isso, garantir a sobrevivência, muitos indivíduos recorreram a alternativas ao capitalismo desenfreado, típico da sociedade globalizada. Acerca dessa situação é que discutiremos nos próximos tópicos com o objetivo de buscar compreender o modo como essa parcela da população convive com as novas características da economia e, além disso, os fatores que podem contribuir para que 0 reconhecimento dessas pessoas seja pleno. 


\section{ANÁLISE DAS ETAPAS DA TEORIA DO RECONHECIMENTO EM AXEL HONNETH}

A teoria do reconhecimento será analisada a partir das considerações de Axel Honneth, que, por sua vez, buscou os seus principais conceitos e a ideia de reconhecimento recíproco nos ensinamentos de Hegel, além de ter adotado algumas categorias de Winnicott e Mead para a apresentação das três etapas que fundam a teoria.

Para Honneth" ${ }^{12}$, a palavra "reconhecimento" possui diversos significados pelo fato de que não se consagra em um conceito claro e unívoco e isso implica dizer que cada significado conferido ao termo está ligado, por conseguinte, “[...] a uma perspectiva moral específica”.

Sobre os diversos significados de "reconhecimento", Honneth ${ }^{13}$ destaca os seguintes:

no contexto da formulação de uma ética feminista, esse conceito é utilizado, acima de tudo, para caracterizar o tipo de atenção amorosa e atenciosa exemplificado no relacionamento entre mãe e filho. Em uma ética do discurso, ao contrário, o "reconhecimento" refere-se ao respeito recíproco para o status único e igual de todos os outros; aqui, a conduta esperada dos participantes em um discurso serve como um modelo paradigmático. Finalmente, dentro da estrutura de esforços direcionada a desenvolver melhor as ideias comunitaristas, a categoria do reconhecimento é empregada, hoje, para caracterizar as formas pelas quais as outras maneiras de vida passam a ser estimadas, como exemplificado mais tipicamente no caso da solidariedade social.

A fim de descrever as etapas de reconhecimento pelas quais um indivíduo passa - ou tem que superar - ao longo da vida, Honneth busca nos estudos de Hegel, Winnicut e Mead as concepções necessárias para construir a sua visão acerca da teoria do reconhecimento, que se perfaz pela etapa do "amor", dos “direitos" e da "solidariedade". Em resumo, Nelson Moreira ${ }^{14}$ ressalta que

os padrões de reconhecimento intersubjetivo ocorrem em três etapas: (a) primeiramente, na esfera das relações primárias, a forma de reconhecimento

\footnotetext{
12 HONNETH, Axel. Reconhecimento ou redistribuição? A mudança de perspectivas na ordem moral da sociedade. In: SOUZA, Jessé; MATTOS, Patrícia (Orgs.). Teoria crítica no século XXI. São Paulo: Annablume, 2007, p. 82.

13 Ibidem.

14 MOREIRA, Nelson Camatta. Fundamentos de uma teoria da constituição dirigente. Florianópolis: Conceito Editorial, 2010. p. 57.
} 
GLOBALIZAÇÃO, INVISIBILIDADE SOCIAL E RECONHECIMENTO: UMA ANÁLISE DA (SO)NEGAÇÃO DE DIREITOS DOS CATADORES DE MATERIAIS RECICLÁVEIS

NeLson CAMATTA MOREIRA PRISCILA TINELLI PINHEIRO

relaciona-se ao amor e à amizade; (b) na segunda, na dimensão das relações jurídicas, o reconhecimento se identifica com direitos; e, por fim, (c) na comunidade valorativa, a maneira de reconhecimento é a solidariedade.

No que tange a primeira etapa do reconhecimento - o "amor" - destaca-se que o seu estabelecimento ocorre nas primeiras relações travadas com indivíduo após o seu nascimento. Honneth, com base na categoria da dependência absoluta de Winnicut, descreve o desenvolvimento da criança e a sua relação com a mãe, a qual inicia-se com uma "dependência absoluta", em que o indivíduo necessita da mãe para realizar todas as atividades para sua sobrevivência e transforma-se, por meio de um fenômeno - denominado por ele de destruição e transição - em que a criança luta pela sua independência ${ }^{15}$.

Observa-se que, nesse primeiro momento, as relações estabelecidas entre o indivíduo e o mundo são restritas ao âmbito familiar, pois ele ainda não tem contato com o mundo. Nesse caso, portanto, “[...] o reconhecimento [...] tem que possuir o caráter de aceitação e encorajamento afetivo"16.

É nessa primeira etapa que se desenvolve a “autoconfiança” - necessária ao reconhecimento recíproco - que se refere “[...] à camada fundamental de autoconfiança emocional e corporal na expressão das necessidades e sentimentos do indivíduo, que forma as pré-condições psicológicas para o desenvolvimento de todos os outros aspectos de autorespeito" ${ }^{17}$.

Nesse sentido, o autor salienta que "quando a criança experimenta a confiança no cuidado paciencioso e duradouro da mãe, ela passa a estar em condições de desenvolver uma relação positiva consigo mesma ${ }^{18}$.

Acerca dessa primeira etapa do reconhecimento, pode-se inferir que ela trata de forma específica das relações emocionais que o indivíduo pode estabelecer no seu ambiente familiar, nas suas amizades, pois refere-se - de forma bem simplista - ao seu fortalecimento individual para depois partir para um espaço mais abrangente. É como se o indivíduo precisa-se se

\footnotetext{
15 SAAVEDRA, Giovani Agostini. A teoria crítica de Axel Honneth. In: SOUZA, Jessé; MATTOS, Patrícia (Orgs.). Teoria crítica no século XXI. São Paulo: Annablume, 2007. p. 103.

16 HONNETH, Axel. Reconhecimento ou redistribuição? A mudança de perspectivas na ordem moral da sociedade. In: SOUZA, Jessé; MATTOS, Patrícia (Orgs.). Teoria crítica no século XXI. São Paulo: Annablume, 2007. p. 85.

17 Ibidem. p. 86.

18 SAAVEDRA, Giovani Agostini. A teoria crítica de Axel Honneth. In: SOUZA, Jessé; MATTOS, Patrícia (Orgs.). Teoria crítica no século XXI. São Paulo: Annablume, 2007. p. 95-104.
} 
estabelecer primeiro com a sua família e ao mesmo tempo com o seu "interior" para depois galgar novas relações.

Já a segunda etapa do reconhecimento trata da relação do indivíduo em relação aos direitos que the são concedidos. Nesse segundo momento, a visão do indivíduo passa a ser a partir dos seus direitos e os direitos do outro com o objetivo de se verificar a questão de igualdade. Trata-se, portanto, de uma espécie de reconhecimento legal na esfera das relações jurídicas.

Isso significa que "[...] os indivíduos passam a se considerar como portadores iguais dos direitos a partir da perspectiva de seus companheiros"19. Dessa forma, "a atitude positiva que os sujeitos podem tomar em relação a si mesmos, quando eles adquirem esse reconhecimento legal, é a de um auto-respeito elementar"20.

A partir dessa ideia de auto-respeito, levantada pelo autor ao se referir ao reconhecimento recíproco, é possível introduzir “[...] a dimensão da alteridade no âmbito das interações sociais, através de um processo de reconhecimento mútuo, que Mead chama de outro generalizado"21.

Nessa segunda etapa, observa-se que o indivíduo busca - para ser reconhecido - a efetivação de seus direitos e, dessa forma, aumento o espaço das suas relações, uma vez que já não se restringe somente à família e amigos, mas a partir do “outro" - que também é um habitante da sua sociedade - ele almeja uma igualdade de direitos fornecidos pelo Estado.

Por último, a terceira etapa do reconhecimento trata do indivíduo no âmbito do desenvolvimento de valores perante a comunidade a qual habita. Assim, numa perspectiva de solidariedade, o indivíduo é capaz de desenvolver, de forma positiva, a auto-estima, pois na medida em que “[...] se achar estimado por suas qualidades específicas, o sujeito é capaz de se identificar totalmente com seus atributos e realizações específicas”22.

\footnotetext{
19 HONNETH, Axel. Reconhecimento ou redistribuição? A mudança de perspectivas na ordem moral da sociedade. In: SOUZA, Jessé; MATTOS, Patrícia (Orgs.). Teoria crítica no século XXI. São Paulo: Annablume, 2007. p. 85.

${ }^{20}$ Ibidem. p. 86.

21 MOREIRA, Nelson Camatta. Fundamentos de uma teoria da constituição dirigente. Florianópolis: Conceito Editorial, 2010. p. 58.

${ }^{22}$ HONNETH, Axel. Reconhecimento ou redistribuição? A mudança de perspectivas na ordem moral da sociedade. In: SOUZA, Jessé; MATTOS, Patrícia (Orgs.). Teoria crítica no século XXI. São Paulo: Annablume, 2007, p. 87.
} 
GLOBALIZAÇÃO, INVISIBILIDADE SOCIAL E RECONHECIMENTO: UMA ANÁLISE DA (SO)NEGAÇÃO DE DIREITOS DOS CATADORES DE MATERIAIS RECICLÁVEIS

NeLson CAMATTA MOREIRA PRISCILA TINELLI PINHEIRO

De acordo com o autor, “[...] o relacionamento de reconhecimento associado à solidariedade incorpora o princípio da diferença igualitária, que, resultante da pressão que vem dos sujeitos individualizados, pode se desenvolver mais plenamente"23.

Nesse sentido, "a solidariedade está vinculada na sociedade moderna à condição de relações sociais simétricas de estima entre indivíduos autônomos e à possibilidade de os indivíduos desenvolverem a sua auto-realização"24.

Com base nos diversos tipos de reconhecimento que podem ser estabelecidos e nas etapas propostas para que tal situação seja plena, destaca-se que somente é possível discutir acerca do reconhecimento quando houver, por outro lado, um sentimento de injustiça. Tal sentimento pode surgir em virtude de diversas formas de desrespeito - denominadas de "patologias" por Honneth.

Nesse sentido, o autor

[...] procura mostrar que uma experiência social de desrespeito atua como uma forma de freio social que pode levar à paralisia do indivíduo ou de um grupo social. Por outro lado, ela mostra o quanto o ator social é dependente do reconhecimento social. Honneth sustenta que o indivíduo está sempre vinculado em uma complexa rede de relações intersubjetivas, e que, consequentemente, ele é dependente estruturalmente do reconhecimento dos outros indivíduos. A experiência do desrespeito, então, deve ser tal que forneça a base motivacional da luta por reconhecimento, porque essa tensão afetiva só pode ser superada quando o ator social estiver em condições de voltar a ter uma participação ativa e sadia na sociedade ${ }^{25}$.

O indivíduo, dessa forma, só não tem o seu devido reconhecimento - relação que só pode ser estabelecida a partir da visão do outro sobre ele - quando sofre com as referidas "patologias". Para cada etapa do reconhecimento, Honneth destaca um sentimento de injustiça que deve ser superado para que ela se estabeleça plenamente. Pode-se afirmar, portanto, que “[...] a negação do reconhecimento de alguém implica a privação de um pré-requisito básico para o seu reconhecimento humano"26.

\footnotetext{
23 Ibidem.

24 SAAVEDRA, Giovani Agostini. A teoria crítica de Axel Honneth. In: SOUZA, Jessé; MATTOS, Patrícia (Orgs.). Teoria crítica no século XXI. São Paulo: Annablume, 2007, p. 107.

${ }_{25}$ SAAVEDRA, Giovani Agostini. A teoria crítica de Axel Honneth. In: SOUZA, Jessé; MATTOS, Patrícia (Orgs.). Teoria crítica no século XXI. São Paulo: Annablume, 2007, p. 109.

26 MOREIRA, Nelson Camatta. Fundamentos de uma teoria da constituição dirigente. Florianópolis: Conceito Editorial, 2010. p. 60.
} 
Acerca das "patologias" que impedem que o reconhecimento estabeleça-se por completo, Honneth destaca, para cada etapa descrita - amor, direito e solidariedade - uma forma correspondente de desrespeito que ocorre e, por isso, falar-se em reconhecimento.

A primeira etapa do reconhecimento, como já descrito, trata da esfera do amor que diz respeito às primeiras relações do sujeito com no âmbito familiar. Nesse sentido, as formas de desrespeito elencadas pelo autor são os maus tratos e a violação. Assim,

nesta forma de desrespeito o componente da personalidade atacado é aquele da integridade psíquica, ou seja, não é diretamente a integridade física que é violentada, mas sim o auto-respeito [...] que cada pessoa possui de seu corpo e que é adquirido por meio do processo intersubjetivo de socialização originado através da dedicação afetiva ${ }^{27}$.

Por isso que essa etapa somente pode ser analisada no âmbito das relações afetivas, uma vez que ela corresponde exclusivamente ao lado emocional do indivíduo.

Já na segunda etapa, essas relações primárias são substituídas pela perspectiva do indivíduo a partir do "outro" - o qual é sujeito de direitos. Nesse sentido,

[...] estamos aqui lidando com a negação dos direitos e com a exclusão social, em que seres humanos padecem em sua dignidade por não terem concedidos de si os direitos morais e as responsabilidades de uma pessoa legal plena em sua própria comunidade ${ }^{28}$.

Nessa perspectiva, a "patologia” que se apresenta nessa segunda etapa é justamente a privação de direitos por parte do Estado. Por conseguinte, “[...] o componente da personalidade que é ameaçado é aquela integridade social"29.

A terceira forma de desrespeito ao sujeito é, segundo Honneth, a degradação moral e a injúria - componente da terceira etapa do reconhecimento: solidariedade. Ela se perfaz, dessa forma, quando a pessoa encontra-se “[...] privada da possibilidade de desenvolver uma estima

\footnotetext{
27 SAAVEDRA, Giovani Agostini. A teoria crítica de Axel Honneth. In: SOUZA, Jessé; MATTOS, Patrícia (Orgs.). Teoria crítica no século XXI. São Paulo: Annablume, 2007, p. 108.

28 HONNETH, Axel. Reconhecimento ou redistribuição? A mudança de perspectivas na ordem moral da sociedade. In: SOUZA, Jessé; MATTOS, Patrícia (Orgs.). Teoria crítica no século XXI. São Paulo: Annablume, 2007, p. 86.

29 SAAVEDRA, Giovani Agostini. A teoria crítica de Axel Honneth. In: SOUZA, Jessé; MATTOS, Patrícia (Orgs.). Teoria crítica no século XXI. São Paulo: Annablume, 2007, p. 108.
} 
positiva de si mesma" 30 . Assim, "Honneth entende que a dimensão da personalidade ameaçada é aquela da dignidade $[\ldots]$...31.

O autor, sobre essa terceira forma de desrespeito, acrescenta que

esse padrão de desvalorização dos feitos ou formas específicas de vida resulta em não permitir que os sujeitos em questão se relacionem com as habilidades adquiridas ao longo de suas vidas, em relação à estima social ${ }^{32}$.

A partir das considerações apresentadas sobre a teoria proposta pelo Honneth, infere-se que para um indivíduo - ou mesmo um grupo social - atingir o adequado reconhecimento é necessário o preenchimento das três etapas descritas: o amor, o direito e a solidariedade. 0 que nos remete a concluir que, por outro lado, quando não se preenche de forma adequada qualquer uma das etapas propostas, não se adquire, por conseguinte, o devido reconhecimento.

Com isso, o último tópico destina-se a discutir de forma específica, tomando por base as considerações anteriores sobre a globalização econômica e as etapas da teoria do reconhecimento, a realidade vivida atualmente pelos catadores de materiais recicláveis a partir dos obstáculos enfrentados para se alcançar o devido reconhecimento.

\section{CATADORES DE MATERIAIS RECICLÁVEIS: OS INVISÍVEIS DA SOCIEDADE GLOBALIZADA}

Para realizar uma análise dos catadores de materiais recicláveis e os obstáculos que enfrentam para o reconhecimento perante o processo de globalização, é necessário - em primeiro lugar - que seja traçado o perfil social desse grupo, bem como suas conquistas até hoje alcançadas e o que ainda precisa ser obtido nessa luta pela sobrevivência.

Em uma sociedade, cujo modelo sócio econômico vigente é o do capitalismo, a lógica do mercado impera sobre a vida de todos os seus habitantes é excludente. Ou seja, trata-se de um sistema que criado para atender a determinadas pessoas ou grupos sociais, que são os

\footnotetext{
30 Ibidem. p. 109.

31 Ibidem. p. 108.

32 HONNETH, Axel. Reconhecimento ou redistribuição? A mudança de perspectivas na ordem moral da sociedade. In: SOUZA, Jessé; MATTOS, Patrícia (Orgs.). Teoria crítica no século XXI. São Paulo: Annablume, 2007. p. 87.
} 
GLOBALIZAÇÃO, INVISIBILIDADE SOCIAL E RECONHECIMENTO: UMA ANÁLISE DA (SO)NEGAÇÃO DE DIREITOS DOS CATADORES DE MATERIAIS RECICLÁVEIS

NeLson CAMATTA MOREIRA PRISCILA TINELLI PINHEIRO

capitalistas, sendo todos os demais excluídos, deixados à margem, daí o fato do grande contingente de desempregados, os quais não se enquadraram neste modelo de produção.

O capitalismo, além de constituir-se essencialmente num sistema econômico, pode ser analisado como uma forma de organização da própria sociedade que dele se utiliza. Isto significa que a análise da sua lógica de funcionamento pode ultrapassar a esfera econômica e adentrar nos aspectos sociais de determinada comunidade.

Em decorrência da lógica que impera no capitalismo determinar que o trabalhador para entrar e manter-se no mercado de trabalho - é obrigado a vender a sua força de trabalho, os críticos ao capitalismo entendem que esta situação é apenas mais um traço de que tudo que está à volta deste modelo econômico deve ser transformado em mercadoria ${ }^{33}$. Isso porque como será elucidado adiante - o principal produto do capitalismo é justamente o alcance de lucro $^{34}$, o qual é proporcionado pela geração de capital ${ }^{35}$.

A partir da perspectiva de que o capitalismo tem como mecanismo precursor do seu modelo econômico e organizacional a redução dos seus componentes a mercadorias, Wolkmer ${ }^{36}$ aduz que

[...] diante dos recentes processos de dominação e exclusão produzidas pela globalização, pelo capital financeiro e pelo neoliberalismo que vem afetando substancialmente relações sociais, formas de representação e de legitimação, impõe-se repensar politicamente o poder de ação da comunidade, o retorno dos agentes históricos, o aparecimento inédito de direitos relacionados às minorias e à produção alternativa de jurisdição, com base no viés interpretativo da pluralidade de fontes.

\footnotetext{
${ }^{33}$ Para Karl Marx, "a mercadoria é [...] um objeto externo, uma coisa que, por suas propriedades, satisfaz necessidades humanas, seja qual for a natureza, a origem delas, provenham do estômago ou da fantasia. Não importa a maneira como a coisa satisfaz a necessidade humana, se diretamente, como meio de subsistência, objeto de consumo, ou indiretamente, como meio de produção". Nesse sentido, conferir MARX, Karl. O capital: crítica da economia política: livro I. Tradução de Reginaldo Sant'Anna. 21. ed. Rio de Janeiro: Civilização Brasileira, 2003, p. 57.

${ }^{34}$ A base do lucro capitalista constitui-se do valor "a mais" resultante da diferença entre o valor final da mercadoria produzida e a junção do valor gasto com os meios de produção e com o trabalho, que é justamente a mais-valia, ou seja, o valor excedente resultante produção e da venda de mercadorias. Nesse sentido, conferir SINGER, Paul. O capitalismo: sua evolução, sua lógica e sua dinâmica. Coleção Polêmica. São Paulo: Moderna, 1987, p. 30.

35 De acordo com Paul Singer, "capital é [...] uma relação social que se materializa em objeto: em dinheiro, em meios de produção, em trabalho pago por salário, em produtos vendidos em mercados". Nesse sentido, conferir SINGER, Paul. O capitalismo: sua evolução, sua lógica e sua dinâmica. Coleção Polêmica. São Paulo: Moderna, 1987, p. 29.

36 WOLKMER, Antônio Carlos. Pluralismo jurídico, direitos humanos e interculturalidade. Revista Sequência. n. 53, p. 113-118, dez., 2006, p. 114.
} 
Isso significa, na visão do autor, que o capitalismo possui um potencial capaz de transformar as próprias relações sociais em mercadorias e, com esta situação, segregar a sociedade sob a qual ele se instala.

Uma segunda característica atribuída ao sistema capitalista “[...] é a produção da maisvalia como finalidade direta e móvel determinante da produção. 0 capital produz essencialmente capital e, para poder fazê-lo, não tem outro caminho a não ser produzir maisvalia" ${ }^{37}$. Sobre esta característica, convém destacar que, para que a lógica do sistema funcione de maneira adequada, é necessário lembrar que "só importa o tempo que o trabalhador leva para executar a operação ou o período durante o qual a força de trabalho é gasta utilmente" 38

Desta forma, a mais-valia torna-se fundamental para o capitalismo na medida em que ela é originária “[...] de um excedente quantitativo de trabalho, da duração prolongada do mesmo processo de trabalho [...]"39, ou seja, além do indivíduo despender sua força de trabalho para a construção de determinada mercadoria - processo principal da produção - ele também produz um excedente, que contribuirá para a produção, mas não the será retribuído na forma de remuneração, pois este se constitui no próprio lucro revertido em proveito exclusivo do capitalista.

A partir destas características essenciais do sistema capitalista apontadas por Karl Marx, é possível observar que o modelo capitalista compõe-se de certas contradições. Estas, por sua vez, giram, essencialmente, em torno da exploração do trabalho, pois para que o principal fim perseguido pelo capitalismo seja alcançado, ou seja, para a obtenção da mais-valia - compra-se a força de trabalho daquele indivíduo que a coloca a venda também como uma mercadoria.

$\mathrm{Na}$ perspectiva do referido autor, a transformação da sociedade pelo desenvolvimento de contradições contribui para a análise da própria sociedade atual ${ }^{40}$, uma vez que as relações sociais travadas na contemporaneidade também pressupõem contradições.

\footnotetext{
${ }^{37}$ IANNI, Octávio. A sociedade global. 8. ed. Rio de Janeiro: Civilização Brasileira, 1999. p. 78.

${ }^{38}$ MARX, Karl. O capital: crítica da economia política: livro I. Tradução de Reginaldo Sant'Anna. 21. ed. Rio de Janeiro: Civilização Brasileira, 2003, p. 228.

${ }^{39}$ MARX, Karl. O capital: crítica da economia política: livro I. Tradução de Reginaldo Sant'Anna. 21. ed. Rio de Janeiro: Civilização Brasileira, 2003, p. 231.

40 SANTOS, Boaventura de Sousa. Pela mão de Alice: o social e o político na pós-modernidade. 9. ed. São Paulo: Cortez, 2003, p. 44.
} 
Evidencia-se, assim, esta situação de contradição na própria divisão da sociedade capitalista, a qual é constituída essencialmente por dois principais grupos: aqueles que detêm os meios de produção (os capitalistas) e aqueles que não os detêm e, por isso, vendem sua força de trabalho em troca de salário buscando a sobrevivência (o trabalhador).

Do mesmo modo, Paul Singer ${ }^{41}$ afirma que é nítida esta divisão de grupos provocada na sociedade capitalista, já que o capitalismo apresenta-se como um "sistema sócio-econômico em que os meios de produção são propriedade privada duma classe social em contraposição a outra classe de trabalhadores não-proprietários".

É o que corrobora Wolkmer ${ }^{42}$ ao afirmar que

O florescimento do capitalismo, como ápice de toda estrutura econômica da sociedade moderna resultante da perda de autonomia por parte dos pequenos produtores e da separação de seus instrumentos de produção e de subsistência, e da transformação da força de trabalho em mercadoria - criará possibilidades para a concomitante formação de uma nova classe social proprietária que monopolizará os meios de produção.

Neste sentido, identifica-se a sociedade capitalista como "uma sociedade em que o dinheiro é o representante geral da riqueza, em que os meios de produção são produzidos e alienados como mercadorias e em que os trabalhadores, em boa parte, vendem sua força de trabalho para sobreviver [...]"43.

Em decorrência do impacto acarretado pelo modelo econômico em análise na estrutura da sociedade, Boaventura de Sousa Santos ${ }^{44}$ entende que "o capitalismo é hoje menos um modo de produção que um modo de vida", isto porque em sua perspectiva

0 individualismo e o consumismo transferiram para a esfera privada a equação entre interesse e capacidade. É nessa esfera que hoje os indivíduos identificam melhor os seus interesses e as capacidades para lhes dar satisfação. A redução à esfera privada desta equação faz com que muitas das desigualdades e opressões

\footnotetext{
${ }^{41}$ SINGER, Paul. O capitalismo: sua evolução, sua lógica e sua dinâmica. Coleção Polêmica. São Paulo: Moderna, 1987, p. 7.

42 WOLKMER, Antônio Carlos. Pluralismo jurídico, direitos humanos e interculturalidade. Revista Sequência. n. 53, p. 113-118, dez., 2006, p. 34.

43 SINGER, Paul. O capitalismo: sua evolução, sua lógica e sua dinâmica. Coleção Polêmica. São Paulo: Moderna, 1987, p. 28.

${ }^{44}$ SANTOS, Boaventura de Sousa. Pela mão de Alice: o social e o político na pós-modernidade. 9. ed. São Paulo: Cortez, 2003, p. 320.
} 
que ocorrem em cada um dos espaços-tempo estruturais sejam invisíveis ou, se visíveis, trivializadas.

As desigualdades e a opressão mencionadas pelo autor apresentam-se como inevitáveis para a manutenção da lógica capitalista, pois para que o detentor dos meios de produção produza mercadorias é preciso que, em contrapartida, existam indivíduos dispostos a vender sua mão-de-obra. Além disso, o acúmulo de riqueza por meio do lucro pressupõe o aumento da diferença entre o valor destinado à despesa com a produção da mercadoria e daquele gasto com os meios de produção. Logo, identifica-se - num primeiro momento - apenas duas alternativas para tornar possível esta situação, quais sejam: a redução dos custos com a matéria-prima e com os meios de produção.

Nessa perspectiva, Bauman ${ }^{45}$ faz uma importante reflexão acerca da palavra “desemprego" por meio da seguinte passagem extraída de uma de suas obras:

O prefixo "des" indica anomalia. "Desemprego" é o nome de uma condição claramente temporária e anormal, e, assim, a natureza transitória e curável da doença é patente. A noção de "desemprego" herdou sua carga semântica da autoconsciência de uma sociedade que costumava classificar seus integrantes, antes de tudo, como produtores, e que também acreditava no pleno emprego não apenas como condição desejável e atingível, mas também como seu derradeiro destino. Uma sociedade que, portanto, classificava o emprego como uma chave - a chave - para a solução dos problemas ao mesmo tempo da identidade pessoal socialmente aceitável, da posição social segura, da sobrevivência individual e coletiva, da ordem social e da reprodução sistêmica.

Para o autor, "no carro do progresso, o número de assentos e de lugares em pé não é, em regra, suficiente para acomodar todos os passageiros potenciais, e a admissão sempre foi seletiva" ${ }^{46}$, o que implica dizer que além de não ter emprego para todos os habitantes da sociedade, o número disponível de vagas é limitado a uma parcela da sociedade que preenche determinados requisitos impostos pelo mercado, daí advém a questão da seletividade.

Já num segundo momento, nota-se o crescimento alarmante do setor informal - uma das consequências negativas da reestruturação do capitalismo - e o início da busca por formas de

\footnotetext{
45 BAUMAN, Zygmunt. Vidas desperdiçadas. Tradução de Alberto Medeiros. Rio de Janeiro: Jorge Zahar Ed., 2005, p. 19.

46 BAUMAN, Zygmunt. Vidas desperdiçadas. Tradução de Alberto Medeiros. Rio de Janeiro: Jorge Zahar Ed., 2005, p. 24.
} 
produção alternativas ao capitalismo que se tornaram opções de trabalho para aqueles que antes se encontravam diante da realidade do desemprego.

0 trabalho, nessa nova estruturação da sociedade, permite que os indivíduos que produzem possuam o seu lugar garantido, enquanto que aqueles que se encontram fora do mercado produtor - seja por estarem desempregados ou por não preencherem os requisitos necessários a ocupação de uma vaga de trabalho - são considerados excluídos da sociedade.

Observa-se, então, que o trabalho passou a ser um instrumento de reconhecimento dos indivíduos na sociedade, ou seja, "[...] o trabalho deixou de ser uma atividade vil e passou a ser gerador de dignidade e reconhecimento social, causando assim o surgimento de uma moral única e válida para todos" ${ }^{\prime 4}$.

O grande problema dessa realidade - como já descrito - é a insuficiência de trabalho e a questão da seletividade e exclusão do mercado. Podemos nos questionar, a partir dessas afirmações, a forma pela qual os indivíduos driblam esses problemas e tentam sobreviver frente a todos esses obstáculos. Para responder a essa questão, analisaremos o exemplo dos catadores que materiais recicláveis - que é nosso objeto de estudo no presente trabalho.

Destaca-se que a história dos catadores surgiu exatamente a partir do que foi tratado no início desse tópico - acerca do desemprego em massa, poucas opções de emprego e seletividade do mercado. Assim, relegados à margem da sociedade, pelo fato de não pertencerem à parcela produtiva da população, encontraram no que é descartado como “lixo”, pela sociedade, sua fonte de trabalho e sobrevivência.

Acerca da atividade desenvolvida pelos catadores de materiais recicláveis, Bauman ${ }^{48}$ destaca que

Os coletores de materiais recicláveis são os heróis não decantados da modernidade. Dia após dia, eles reavivam a linha de fronteira entre normalidade e patologia, saúde e doença, desejável e repulsivo, aceito e rejeitado [...] Essa fronteira precisa da constante diligência e vigilância porque não é absoluta absolutamente uma "fronteira natural": não há montanhas altíssimas, oceanos sem fundo ou gargantas intransponíveis separando o dentro do fora. E não é a diferença entre produtos úteis e refugo que demarca a divisa. Muito pelo

\footnotetext{
47 MACIEL, Fabrício. Todo trabalho é digno? Um ensaio sobre moralidade e reconhecimento na modernidade periférica. In: SOUZA, Jessé (Org.). A invisibilidade da desigualdade brasileira. Belo Horizonte: Editora UFMG, 2006. p. 300.

48 BAUMAN, Zygmunt. Vidas desperdiçadas. Tradução de Alberto Medeiros. Rio de Janeiro: Jorge Zahar Ed., 2005, p. 39.
} 
GLOBALIZAÇÃO, INVISIBILIDADE SOCIAL E RECONHECIMENTO: UMA ANÁLISE DA (SO)NEGAÇÃO DE DIREITOS DOS CATADORES DE MATERIAIS RECICLÁVEIS

NeLson CAMATTA MOREIRA PRISCILA TINELLI PINHEIRO

contrário, é a divisa que prediz - literalmente, invoca - a diferença entre eles: a diferença entre o admitido e o rejeitado, o incluído e o excluído.

A coleta seletiva, nesse sentido, passou a ser a única fonte de renda dessas pessoas e, após um período de luta e enfrentamento de muitos obstáculos, a atividade desenvolvida pelos catadores passou a ser reconhecida como uma ocupação pela Classificação Brasileira de Ocupações $(C B O)^{49}$, ou seja, o que antes era somente mais uma atividade informal passou a ter certo reconhecimento pelo Estado.

Nessa perspectiva, a Cartilha dos Direitos Humanos dos Catadores de Materiais Recicláveis ${ }^{50}$ elenca as principais conquistas obtidas pela categoria, quais sejam: criação de políticas municipais de coleta seletiva com a inclusão social de catadores; destinação de imóveis vazios para área de trabalho e moradia de catadores; a criação do Comitê Interministerial de Inclusão Social e Econômica dos Catadores de Materiais Recicláveis (Decreto de 11/09/2003); alteração da Lei 8666/83 (Licitações) que dispensa a licitação para as cooperativas e associações de catadores e, por último, a aprovação da Lei Nacional de Saneamento 11.445 de 2007, que inicia o tratamento da política de resíduos sólidos.

Porém, esses foram somente os primeiros passos frente aos inúmeros obstáculos enfrentados por esses indivíduos em relação ao mercado produtor, uma vez que os catadores ainda são vítimas de inúmeras violações aos direitos fundamentais, além do processo de descriminação ao qual encontram-se inseridos.

É importante destacar, dessa forma, que os catadores que atuam nas ruas enfrentam obstáculos ainda maiores do que aqueles que se encontram nas associações. E é justamente por isso que esta categoria, por meio da sua organização e luta social pelo Movimento Nacional dos

\footnotetext{
49 De acordo com o Ministério do Trabalho e Emprego, a ocupação número 5.192-5 - que corresponde à atividade desenvolvida pelo catador de material reciclável - pode ser caracterizada da seguinte forma: os trabalhadores da coleta e seleção de material reciclável são responsáveis por coletar material reciclável e reaproveitável, vender material coletado, selecionar material coletado, preparar o material para expedição, realizar manutenção do ambiente e equipamentos de trabalho, divulgar o trabalho de reciclagem, administrar o trabalho e trabalhar com segurança. Nesse sentido, conferir MTE - MINISTÉRIO DO TRABALHO E EMPREGO. Classificação Brasileira de Ocupações. Disponível em: http://www.mtecbo.gov.br/cbosite/pages/home.jsf. Acesso em: 17 dez. 2016.

${ }^{50}$ MNCR - MOVIMENTO NACIONAL DOS CATADORES DE MATERIAIS RECICLÁVEIS. Cartilha de formação: os direitos humanos e os catadores de materiais recicláveis. Disponível em: <www.mncr.org.br/>. Acesso em: 21 jun. 2014, p. 22.
} 
GLOBALIZAÇÃO, INVISIBILIDADE SOCIAL E RECONHECIMENTO: UMA ANÁLISE DA (SO)NEGAÇÃO DE DIREITOS DOS CATADORES DE MATERIAIS RECICLÁVEIS

NeLson CAMATTA MOREIRA PRISCILA TINELLI PINHEIRO

Catadores de Materiais Recicláveis ${ }^{51}$ incentivam aqueles que ainda desenvolvem suas atividades nas ruas para que se associem e, com isso, possam executar seu trabalho de forma digna.

Nas ruas, os catadores estão sujeitos, por exemplo, a atividade dos chamados atravessadores, os quais “[...] fornecem o produto para a empresa recicladora, explorando e até mesmo humilhando os catadores enquanto ganham lucros altíssimos". Com a prática desses indivíduos, surge a chamada servidão por dívida em que os catadores ficam "presos" a eles pelo fato de que parte do dinheiro arrecadado é destinado aos atravessadores, além do lucro que eles obtêm por meio do aluguel de instrumentos de trabalho: as carroças.

Outro problema enfrentado pelos catadores que atuam nas ruas é a apreensão ${ }^{52}$ de suas carroças, o que ocorre pela atuação estatal. Dessa forma, com frequência os catadores são “[...] repreendidos pela polícia ou pelas guardas municipais para não terem acesso às ruas das cidades [...] o que eles chamam de 'limpeza' nas cidades, tratando de forma absurda os trabalhadores como 'sujeira humana'53. Assim, sem o seu instrumento de trabalho, os catadores são impedidos de forma brutal de desenvolverem sua atividade laboral.

Como último exemplo de atrocidades cometidas contra os catadores, podemos citar a discriminação e a violência tanto física quanto moral. Nesse sentido, os próprios catadores

\footnotetext{
51 O Movimento Nacional dos Catadores de Materiais Recicláveis (MNCR) é um movimento social que "[...] surgiu em meados de $1999 \mathrm{com}$ o $1^{\circ}$ Encontro Nacional de Catadores de Papel, sendo fundado em junho de 2001 no $1^{\circ}$ Congresso Nacional dos Catadores(as) de Materiais Recicláveis em Brasília, evento que reuniu mais de 1.700 catadores e catadoras". Nesse sentido, conferir MNCR - MOVIMENTO NACIONAL DOS CATADORES DE MATERIAIS RECICLÁVEIS. Cartilha de formação: os direitos humanos e os catadores de materiais recicláveis. Disponível em: < www.mncr.org.br >. Acesso em: 21 jun. 2014, p. 2.

52 Sobre esta situação, "no final de junho, a Defensoria Pública do Estado de São Paulo (DPESP) enviou ofícios à Prefeitura de São Paulo, solicitando que fossem devolvidos bens, objetos pessoais e carroças aos seus donos, pessoas em situação de rua que tiveram tais pertences apreendidos por guardas civis metropolitanos durante as operações que aconteceram na região da Cracolândia, no final do mês de abril. Os pedidos foram enviados às secretarias de Direitos Humanos, de Assistência e Desenvolvimento Social, de Segurança Urbana e de Serviços da prefeitura". De acordo com o texto enviado às secretarias, "Muitas pessoas tiveram suas carroças apreendidas, durante a operação do dia 29 de abril e nos dias seguintes, assim como pertences pessoais diversos. As pessoas utilizavam as carroças para a coleta e transporte de materiais recicláveis, sendo essa uma das únicas fontes de renda que possuíam no contexto de extrema vulnerabilidade social em que vivem". Nesse sentido, conferir MNCR - MOVIMENTO NACIONAL DOS CATADORES DE MATERIAIS RECICLÁVEIS. 0 rapa das carroças. Disponível em: http:// www.mncr.org.br/noticias/blog-sudeste/201co-rapa-das-carrocas201d. Acesso em: 27 ago. 2016. ${ }^{53}$ MNCR - MOVIMENTO NACIONAL DOS CATADORES DE MATERIAIS RECICLÁVEIS. Cartilha de formação: os direitos humanos e os catadores de materiais recicláveis. Disponível em: www.mncr.org.br/. Acesso em: 21 jun. 2014, p. 07-08.
} 
relatam que [...] são várias as situações de espancamentos, atentados contra a vida, realizados pelos atravessadores, polícia, ou funcionários das prefeituras" ${ }^{54}$.

Com relação à discriminação, observa-se a sua ocorrência em virtude de diversos fatores e em variadas ocasiões, mas o motivo mais recorrente é a questão racial e social, uma vez que a maior parte da categoria dos catadores é composta por negros e indivíduos das classes baixas.

Por outro lado, nas associações, os catadores enfrentam, além de algumas das mencionadas violações, obstáculos para o desenvolvimento estrutural, econômico e até mesmo social. Nota-se que, apesar da ideia de reciclagem ter tomado grandes proporções na sociedade brasileira nos últimos anos em virtude da propagação dos conceitos de sustentabilidade e da vantagem econômica que essa atividade gera para o país, ainda é recorrente as dificuldades das associações em gerarem aos seus membros que seja capaz de se igualar, em alguns casos, ao salário mínimo vigente.

Isso decorre, dentre outros fatores da implantação do processo de globalização da economia - já enunciado no primeiro tópico do presente trabalho - o qual tem como uma de suas características o desprivilegio da produção nacional em detrimento da produção de empresas consideradas globais, ou seja, aquelas que possuem alta capacidade produtiva para ir além do espaço local. Surgem, então, o grande impasse sofrido pelas associações, pois sua produção é pequena quando comparada às grandes empresas e o mercado, por sua vez, é complemente cruel e seletivo com essa realidade.

Não podemos olvidar de que para o processo de reciclagem tornar-se rentável, é imprescindível que o preço da matéria-prima - a qual advém da atividade dos catadores mantenha-se inferior ao custo da matéria-prima nova. E essa situação também contribui para que a renda dessa categoria esteja no limite, ou muitas vezes, abaixo do salário mínimo vigente no país, o que torna essa atividade tipicamente de sobrevivência.

Acerca da importância do fomento da atividade de reciclagem, Rodríguez ${ }^{55}$ destaca que

\footnotetext{
${ }^{54}$ MNCR - MOVIMENTO NACIONAL DOS CATADORES DE MATERIAIS RECICLÁVEIS. Cartilha de formação: os direitos humanos e os catadores de materiais recicláveis. Disponível em: www.mncr.org.br/. Acesso em: 21 jun. 2014, p. 12.

55 RODRÍGUEZ, César. À procura de alternativas econômicas em tempos de globalização: o caso das cooperativas de recicladores de lixo na Colômbia. Tradução de Manuel del Pino. In: SANTOS, Boaventura de Sousa (Org.). Produzir para viver: os caminhos da produção não capitalista. 3. ed. Rio de Janeiro: Civilização Brasileira, 2012, p. 340.
} 
GLOBALIZAÇÃO, INVISIBILIDADE SOCIAL E RECONHECIMENTO: UMA ANÁLISE DA (SO)NEGAÇÃO DE DIREITOS DOS CATADORES DE MATERIAIS RECICLÁVEIS

NeLson CAMATTA MOREIRA PRISCILA TINELLI PINHEIRO

a reciclagem de resíduos sólidos recuperáveis ou reutilizáveis - como o papel, o cartão, o vidro, o plástico e o alumínio - é um passo fundamental no ciclo produtivo de numerosas indústrias, especialmente em setores como o da produção de papel, de embalagens e cartão. De fato, boa parte das matériasprimas utilizadas por estas indústrias advém da reciclagem. 0 uso de materiais reciclados na indústria tem efeitos econômicos e ambientais decisivos.

A alternativa que as associações e cooperativas de catadores de materiais recicláveis encontraram para começar a se estabelecer no mercado produtivo e driblar os efeitos da globalização e do capitalismo desenfreado é a adoção, em sua estrutura, de uma forma de produção alternativa ao capitalismo: a economia solidária. Assim, “[...] as cooperativas de trabalhadores visam superar a divisão entre capital e trabalho - e o esquema de propriedade individual e a administração hierárquica que a acompanham - característica das empresas convencionais" $" 56$.

Em linhas gerais, pode-se dizer que o estabelecimento da economia solidária como modelo econômico tem como características fundamentais a solidariedade, a igualdade e a proteção do meio ambiente ${ }^{57}$, além de adotar como modelo de administração a autogestão.

No que tange ao princípio da solidariedade, cumpre salientar que ela se perfaz na medida em que os integrantes do estabelecimento são diferenciados conforme o seu conhecimento técnico e, na falta deste, haverá a troca do conhecimento necessário a realização de determinada tarefa ou ocupação de certo cargo.

Com relação ao princípio da igualdade, destaca-se que essa característica pode ser observada na forma de divisão dos lucros, ou seja, cada trabalhador receberá de forma igualitária o lucro, já que contribui na mesma proporção para que este fosse auferido.

No que diz respeito ao modelo de autogestão, convém fazer uma ressalva no que atine à participação dos trabalhadores, pois não se considera que essa mera participação seja essencialmente a prática de autogerir. De acordo com Carvalho ${ }^{58}$, a autogestão vai além da mera

56 RODRÍGUEZ, César. À procura de alternativas econômicas em tempos de globalização: o caso das cooperativas de recicladores de lixo na Colômbia. Tradução de Manuel del Pino. In: SANTOS, Boaventura de Sousa (Org.). Produzir para viver: os caminhos da produção não capitalista. 3. ed. Rio de Janeiro: Civilização Brasileira, 2012, p. 335.

57 SANTOS, Boaventura de Sousa; RODRÍGUEZ, César. Introdução: para ampliar o cânone da produção. In: SANTOS, Boaventura de Sousa; RODRÍGUEZ, César. Produzir para viver: os caminhos da produção não capitalista. 3. ed. Rio de Janeiro: Civilização Brasileira, 2012. p. 22.

58 CARVALHO, Mariana Costa. Autogestão, Economia solidária e Cooperativismo: uma análise da experiência política da Associação Nacional de Trabalhadores e Empresas de Autogestão. 2012. $116 \mathrm{f}$. Dissertação (Mestrado em Serviço Social). Universidade Federal de Juiz de Fora: Juiz de Fora, 2012. p. 50. 
participação, uma vez que tem como fomento a busca pela democratização da produção e objetiva, como norte maior, a construção de outra sociedade. Desse modo, o modelo de autogestão não se reduz à participação dos trabalhadores ao ambiente da empresa, mas propõem o envolvimento deles nas questões referentes a administração da sociedade como um todo.

Por outro lado, a autogestão, característica da economia solidária, para ser efetiva e se transformar em uma alternativa viável de produção, precisa enfrentar alguns obstáculos que surgem a sua implantação, por exemplo, a ausência de experiência de autogerir por parte dos trabalhadores, o que pode implicar a falta eficiência e criatividade na aplicação do modelo de administração e, com isso, prejudicar os resultados da produção ${ }^{59}$.

Em consonância ao que foi dito sobre a autogestão, vale ressaltar que a sua implantação como modelo de administração nas empresas solidárias deve ocorrer juntamente com os princípios democráticos, pois como já enunciado, todos os trabalhadores devem participar da organização do ambiente de trabalho, ou seja, devem ter voz para decidir as questões gerenciais de forma igualitária, sem que haja o privilégio de uma opinião ou voto em detrimento de outro.

Por uma questão de organização, é comum que haja eleições para compor um grupo de poucos trabalhadores que são responsáveis por aplicar as decisões tomadas pelo restante dos integrantes, como uma diretoria que põe em prática as deliberações da assembleia. Porém, isso não contrapõe de forma alguma a característica de que todos os trabalhadores decidam sobre as questões administrativas, na medida em que é apenas uma forma de potencializar a gestão da empresa.

Com base nas considerações tecidas acerca da atual realidade enfrentada pela categoria dos catadores de materiais recicláveis tanto no exercício de suas atividades nas ruas quanto nas associações/cooperativas, observa-se, em análise às etapas propostas pela teoria do reconhecimento que, de forma geral, eles não possuem esse devido reconhecimento em virtude do não preenchimento das referidas etapas.

Nesse sentido, pode-se inferir, por exemplo, que a segunda etapa - a dos direitos - é a mais prejudicada e isso ocorre justamente pela completa sonegação de direitos trabalhistas previstos na própria Constituição Federal de 1988, pelo artigo $7^{\circ}$, como direitos sociais e

59 CARVALHO, Mariana Costa. Autogestão, Economia solidária e Cooperativismo: uma análise da experiência política da Associação Nacional de Trabalhadores e Empresas de Autogestão. 2012 . $116 \mathrm{f}$. Dissertação (Mestrado em Serviço Social). Universidade Federal de Juiz de Fora: Juiz de Fora, 2012. p. 50. 
garantidos a todos os trabalhadores da sociedade brasileira. Ocorre que - como já mencionado a atividade desenvolvida na coleta seletiva foi reconhecida há pouco tempo como uma ocupação, ou seja, ainda não é classificada, pelo Estado, como uma profissão e, por conseguinte, os catadores não têm acesso a nenhum desses direitos sociais.

Não se pode negar que essa situação constitui um grande avanço no processo de reconhecimento dos catadores, uma vez que até pouco tempo a atividade desenvolvida por eles ocupava o espaço da informalidade e hoje já possui um mínimo de regulamentação. Porém, o fato desse ofício ainda não ser encarado - do ponto de vista formal - como uma profissão representa um grande obstáculo para essas pessoas no que tange a sua afirmação e reconhecimento perante toda a sociedade inclusive o Estado.

Acerca da ausência de preenchimento da segunda etapa da teoria do reconhecimento, Nelson Moreira ${ }^{60}$ destaca a importância do preenchimento dessa etapa em especial em virtude dela tratar justamente dos direitos do indivíduo, o que pode ser observado na seguinte passagem:

O direito [...] constitui uma etapa fundamental do reconhecimento intersubjetivo, consubstanciando instância normativa de afirmação da visibilidade, na medida em que a adjudicação de direitos representa uma dimensão indispensável da cidadania.

Pelo fato deles não terem o devido reconhecimento como profissionais e, por conseguinte, não serem regulamentados pela $\mathrm{CLT}^{61}$ e pela Constituição Federal de 1988, pode-se dizer que esse é um dos principais fatores para considerarmos como invisíveis perante a sociedade.

Nessa perspectiva, Fernando Braga da Costa construiu um conceito para o fenômeno da invisibilidade pública, o qual é recorrente na sociedade contemporânea e atinge diversas práticas e grupos sociais - inclusive o dos catadores de materiais recicláveis que estamos analisando nesse momento. Para o autor, a invisibilidade pública consiste no "desaparecimento intersubjetivo de um homem no meio de outros homens, é expressão pontiaguda de dois

\footnotetext{
60 MOREIRA, Nelson Camatta. Fundamentos de uma teoria da constituição dirigente. Florianópolis: Conceito Editorial, 2010, p. 58.

${ }^{61}$ A sigla CLT corresponde à Consolidação das Leis Trabalhistas, que traz todos os direitos e deveres dos trabalhadores e empregados e de seus respectivos empregadores. Ela é responsável, junto com as legislações trabalhistas esparsas por regulamentar as atividades desenvolvidas pelos brasileiros.
} 
fenômenos psicossociais que assumem caráter crônico nas sociedades capitalistas: humilhação social e reificação"62.

Os fenômenos psicossociais referenciados pelo autor, quais sejam a humilhação social e a reificação se apresentam da seguinte forma:

A humilhação social apresenta-se como um fenômeno histórico, construído e reconstruído ao longo de muitos séculos, e determinante do cotidiano dos indivíduos das classes pobres. É expressão da desigualdade política, indicando exclusão intersubjetiva de uma classe inteira de homens do âmbito público da iniciativa e da palavra, do âmbito da ação fundadora e do diálogo, do governo da cidade e do governo do trabalho. Constitui, assim, um problema político. [...] Reificação é o processo histórico de longa duração através do qual as sociedades modernas fundaram seus alicerces sob o princípio das determinações mercantis. [...] Desse modo, a reificação configura-se como processo pelo qual, nas sociedades industriais, o valor (do que quer que seja: pessoas, relações interhumanas, objetos, instituições) vem apresentar-se à consciência dos homens como valor sobretudo econômico, valor de troca: tudo passa a contar, primariamente, como mercadoria ${ }^{63}$.

Nesse sentido, observa-se que a expressão "invisibilidade pública" nos remete a uma ideia de "cegueira social", a qual envolve toda a sociedade frente a um contexto de exclusão e desigualdade social típico das camadas mais pobres. É como se a população já estivesse acostumada com aquela realidade que se reproduz por diversos anos e, por isso, determinadas situações - como a sonegação de direitos sociais à categoria dos catadores - tornam-se comuns a elas.

Em uma sociedade marcada por grande desigualdade social - como é o caso da brasileira - é necessário que o Estado, por iniciativa dos seus governantes ou mesmo em resposta as diversas lutas promovidas pela categoria em questão acerca da efetivação dos seus direitos enquanto trabalhadores, promova alguma mudança no sentido de atender ao anseio de grupos oprimidos em virtude da falta de direitos.

Seria, portanto, por meio de garantia de direitos - analisados ao longo desse último tópico - que os catadores de materiais recicláveis, sejam aqueles que ainda exercem suas atividades nas ruas ou aqueles que já se tornaram associados de cooperativas e associações

${ }^{62}$ COSTA, Fernando Braga da. Homens invisíveis: relatos de uma humilhação social. São Paulo: Globo, 2004, p. 63.

${ }^{63}$ COSTA, Fernando Braga da. Homens invisíveis: relatos de uma humilhação social. São Paulo: Globo, 2004, p. 63-64, grifo nosso. 
obterão o seu devido reconhecimento e, assim, poderão ser vislumbrados como verdadeiros sujeitos de direitos perante o Estado Democrático Brasileiro.

\section{CONCLUSÃO}

A sociedade brasileira é repleta de desigualdades e essa situação teve o seu agravamento com o processo de globalização - em que para sobreviver no contexto do entrelaçamento de relações sociais, culturais e econômicas - torna-se necessária a produção. Essa busca desenfreada por cada vez se produzir maior volume para atender ao novo mercado foi responsável por retirar força ou mesmo eliminar os serviços mais "simples" e os pequenos produtores da sociedade.

Em uma busca por alternativas de produção a esse novo cenário do mercado, os trabalhadores começaram a implantar técnicas alternativas ao capitalismo - como a economia solidária - que foi citada no presente estudo - a qual foi implantada por cooperativas e associações de catadores de materiais recicláveis com vistas a driblar os efeitos devastadores do citado modelo econômico.

Contudo, somente a implantação de formas alternativas de produção ao capitalismo não se mostra suficiente para a permanência da atividade desenvolvida pelos catadores. Além disso, não é possível conferir um devido reconhecimento - à luz das etapas propostas pela teoria do reconhecimento de Axel Honneth - a essa categoria, tendo em vista a já citada sonegação de direitos sociais que se faz presente, hoje, no Estado Brasileiro.

Como já descrevemos, os catadores de materiais recicláveis constituem um grupo social - vítima do fenômeno da invisibilidade social - e, é possível afirmar, outrossim, que grande parte dessa situação advém da não efetivação dos direitos trabalhistas, já que tal atividade é classificada como uma ocupação e, por isso, excluída do rol de abrangência das normas trabalhistas.

É nítido, portanto, que tal categoria já obteve muitas conquistas ao longo de sua história de luta, porém, ainda resta muito a que se fazer em busca do reconhecimento de tal atividade. Assim, torna-se necessário que o Estado garanta o exercício dos direitos mais básicos desses trabalhadores, tendo em vista a importância da atividade exercida por eles e, ainda mais, pelo fato deles serem cidadãos em um Estado Democrático - como é o brasileiro. 


\section{REFERÊNCIAS}

BAUMAN, Zygmunt. Globalização: as consequências humanas. Tradução de Marcus Penchel. Rio de Janeiro: Jorge Zahar Ed., 1999.

BAUMAN, Zygmunt. Vidas desperdiçadas. Tradução de Alberto Medeiros. Rio de Janeiro: Jorge Zahar Ed., 2005.

CARVALHO, Mariana Costa. Autogestão, Economia solidária e Cooperativismo: uma análise da experiência política da Associação Nacional de Trabalhadores e Empresas de Autogestão. 2012. 116 f. Dissertação (Mestrado em Serviço Social). Universidade Federal de Juiz de Fora: Juiz de Fora, 2012.

COSTA, Fernando Braga da. Homens invisíveis: relatos de uma humilhação social. São Paulo: Globo, 2004.

HINKELAMMERT, Franz J. El proceso actual de globalización y los derechos humanos. In: FLORES, Joaquín Herrera et at (Org.). El vuelto de anteo: derechos humanos y crítica de la razón liberal. Palimpsesto: Desclée de Brouwer, 2000. p. 117-127.

HONNETH, Axel. Reconhecimento ou redistribuição? A mudança de perspectivas na ordem moral da sociedade. In: SOUZA, Jessé; MATTOS, Patrícia (Orgs.). Teoria crítica no século XXI. São Paulo: Annablume, 2007, p. 79-93.

IANNI, Octávio. A sociedade global. 8. ed. Rio de Janeiro: Civilização Brasileira, 1999.

IANNI, Octávio; FERNANDES, Florestan. Marx. 8. ed. Tradução de Maria Elisa Mascarenhas; Ione de Andrade e Fausto N. Pellegrini. Ática: São Paulo, 1996.

IANNI, Octávio. Teorias da globalização. 5. ed. Rio de Janeiro: Civilização Brasileira, 1999.

KUHN, Thomas S. A estrutura das revoluções científicas. Tradução Beatriz Vianna Boeira e Nelson Boeira. 6. ed. São Paulo: Perspectiva, 2001.

MACIEL, Fabrício. Todo trabalho é digno? Um ensaio sobre moralidade e reconhecimento na modernidade periférica. In: SOUZA, Jessé (Org.). A invisibilidade da desigualdade brasileira. Belo Horizonte: Editora UFMG, 2006. p. 285-322.

MARX, Karl. 0 capital: crítica da economia política: livro I. Tradução de Reginaldo Sant'Anna. 21. ed. Rio de Janeiro: Civilização Brasileira, 2003.

MNCR - MOVIMENTO NACIONAL DOS CATADORES DE MATERIAIS RECICLÁVEIS. Cartilha de formação: os direitos humanos e os catadores de materiais recicláveis. Disponível em: www.mncr.org.br/. Acesso em: 21 jun. 2014. 
MNCR - MOVIMENTO NACIONAL DOS CATADORES DE MATERIAIS RECICLÁVEIS. 0 rapa das carroças. Disponível em: http://www.mncr.org.br/noticias/blog-sudeste/201co-rapa-das-carrocas201d. Acesso em: 27 ago. 2016.

MOREIRA, Nelson Camatta. Fundamentos de uma teoria da constituição dirigente. Florianópolis: Conceito Editorial, 2010.

MTE - MINISTÉRIO DO TRABALHO E EMPREGO. Classificação Brasileira de Ocupações. Disponível em: http://www.mtecbo.gov.br/cbosite/pages/home.jsf. Acesso em: 17 dez. 2016.

RODRÍGUEZ, César. À procura de alternativas econômicas em tempos de globalização: o caso das cooperativas de recicladores de lixo na Colômbia. Tradução de Manuel del Pino. In: SANTOS, Boaventura de Sousa (Org.). Produzir para viver: os caminhos da produção não capitalista. 3. ed. Rio de Janeiro: Civilização Brasileira, 2012, p. 331-367.

SAAVEDRA, Giovani Agostini. A teoria crítica de Axel Honneth. In: SOUZA, Jessé; MATTOS, Patrícia (Orgs.). Teoria crítica no século XXI. São Paulo: Annablume, 2007. p. 95-111.

SANTOS, Boaventura de Sousa. Boaventura de Sousa Santos: os processos da globalização. In: SANTOS, Boaventura de Sousa. A globalização e as ciências sociais. São Paulo: Cortez Editora, 2011, p. 25-102.

SANTOS, Boaventura de Sousa. Pela mão de Alice: o social e o político na pós-modernidade. 9. ed. São Paulo: Cortez, 2003.

SANTOS, Boaventura de Sousa; RODRÍGUEZ, César. Introdução: para ampliar o cânone da produção. In: SANTOS, Boaventura de Sousa. Produzir para viver: os caminhos da produção não capitalista. 3. ed. Rio de Janeiro: Civilização Brasileira, 2012, p. 23-74.

SINGER, Paul. O capitalismo: sua evolução, sua lógica e sua dinâmica. Coleção Polêmica. São Paulo: Moderna, 1987.

WOLKMER, Antônio Carlos. Pluralismo jurídico, direitos humanos e interculturalidade. Revista Sequência. n. 53, p. 113-118, dez., 2006.

\section{COMO FAZER A REFERÊNCIA DO ARTIGO (ABNT):}

PINHEIRO, Priscila Tinelli; MOREIRA, Nelson Camatta. Globalização, invisibilidade social e reconhecimento: uma análise da (so)negação de direitos sociais aos catadores de materiais recicláveis. Revista Eletrônica do Curso de Direito da UFSM, Santa Maria, RS, v. 13, n. 1, p. 209-237, abr. 2018. ISSN 1981-3694. Disponível em: < https: //periodicos.ufsm.br/revistadireito/article/view/28699 >. Acesso em: dia mês. ano. doi: http://dx.doi.org/10.5902/1981369428699. 